\title{
Evaluation of marine phytoplankton toxicity by application of marine invertebrate bioassays
}

\author{
Eva Aylagas ${ }^{1}$, Iratxe Menchaca ${ }^{1}$, Aitor Laza-Martínez ${ }^{2}$, Sergio Seoane ${ }^{2}$, Javier Franco ${ }^{1}$ \\ ${ }^{1}$ AZTI-Tecnalia, Marine Research Division, Herrera Kaia, Portualdea, z/g, 20110 Pasaia, Spain. \\ ${ }^{2}$ Department of Plant Biology and Ecology, University of the Basque Country (UPV/EHU), Bilbao, Spain. \\ E-mail: eaylagas@azti.es
}

\begin{abstract}
Summary: The dinoflagellate Alexandrium minutum and the haptophyte Prymnesium parvum are well known for their toxin production and negative effects in marine coastal environments. A. minutum produces toxins which cause paralytic shellfish poisoning in humans and can affect copepods, shellfish and other marine organisms. Toxins of $P$. parvum are associated with massive fish mortalities resulting in negative impacts on the marine ecosystem and large economic losses in commercial aquaculture. The aim of this work is to improve our knowledge about the reliability of the use of marine invertebrate bioassays to detect microalgae toxicity, by performing: (i) a 24- to 48-h test with the brine shrimp Artemia franciscana; (ii) a 48-hour embryo-larval toxicity test with the sea urchin Paracentrotus lividus; and (iii) a 72-h test with the amphipod Corophium multisetosum. The results indicate that $A$. franciscana and $P$. lividus larvae are sensitive to the toxicity of $A$. minutum and $P$. parvum. $\mathrm{LC}_{50}$ comparison analysis between the tested organisms reveals that $A$. franciscana is the most sensitive organism for A. minutum. These findings suggest that the use of different organizational biological level bioassays appears to be a suitable tool for A. minutum and P. parvum toxicity assessment.
\end{abstract}

Keywords: Alexandrium minutum; Prymnesium parvum; Paracentrotus lividus; Artemia franciscana; Corophium multisetosum; toxicity bioassays.

Evaluación de la toxicidad de fitoplancton marino mediante la aplicación de bioensayos con invertebrados marinos

Resumen: Las microalgas Alexandrium minutum y Prymnesium parvum son bien conocidas por la producción de toxinas y sus efectos negativos en nuestras costas. A. minutum produce la toxina PSP (Paralytic Shellfish Poisoning) que afecta a humanos y una gran variedad de organismos marinos como copépodos y marisco. Las toxinas de $P$. parvum producen grandes mortalidades de peces ocasionando graves impactos negativos en el ecosistema marino e importantes pérdidas económicas en acuicultura. Este trabajo tiene como objetivo mejorar el conocimiento del uso de bioensayos con invertebrados marinos en la detección de la toxicidad de microalgas, mediante: (i) un test de 24-48 horas con Artemia franciscana; (ii) un test de 48 horas con embriones y larvas del erizo de mar Paracentrotus lividus; y (iii) un test de 72 horas con el anfípodo Corophium multisetosum. Los resultados muestran que las larvas de A. franciscana y P. lividus son sensibles a la toxicidad de A. minutum y $P$. parvum. Los análisis $\mathrm{LC}_{50}$ revelan que $A$. franciscana es el organismo más sensible a A. minutum. Estos resultados indican que los bioensayos con diferentes niveles de organización biológica parecen ser una herramienta apropiada para la evaluación de la toxicidad de A. minutum y $P$. parvum.

Palabras clave: Alexandrium minutum; Prymnesium parvum; Paracentrotus lividus; Artemia franciscana; Corophium multisetosum; bioensayos de toxicidad.

Citation/Como citar este artículo: Aylagas E., Menchaca I., Laza-Martínez A., Seoane S., Franco J. 2014. Evaluation of marine phytoplankton toxicity by application of marine invertebrate bioassays. Sci. Mar. 78(2): 173-183. doi: http://dx.doi. org/10.3989/scimar.03957.26C

Editor: E. Garcés.

Received: September 12, 2013. Accepted: January 31, 2014. Published: May 26, 2014.

Copyright: (0) 2014 CSIC. This is an open-access article distributed under the Creative Commons Attribution-Non Commercial Lisence (by-nc) Spain 3.0.

\section{INTRODUCTION}

Over the last few decades, the incidence of toxic phytoplankton blooms has apparently been increasing in coastal waters worldwide (GEOHAB 2012). Toxic blooms cause negative impacts and economic losses in many parts of the world and their consequences and mechanisms depend on the species involved. Broadly, there are four categories of deleterious effects: risks to human health; loss of natural or cultured seafood re- 
sources; impairment of tourism and recreational activities; and damage to non-commercial marine resources and wildlife (GEOHAB 2001, Garcés and Camp 2011, Anderson et al. 2012). Several taxonomic groups of microalgae are known as harmful marine species: dinoflagellates, diatoms, raphidophyceans, cyanophytes and haptophytes (Moestrup 1994).

Among the genera responsible for harmful algal blooms (HABs), the genus Alexandrium is one of the most important, in terms of severity, diversity and distribution of bloom impacts (Anderson et al. 2012). Alexandrium minutum Halim is well known for the production of paralytic shellfish poisoning toxins and its presence can affect copepods, shellfish, and other marine organisms (Zhenxing et al. 2006). A. minutum was first described in the Mediterranean Sea forming a red water discoloration in Alexandria Harbour, Egypt (Halim 1960); it has since then been reported widely on the Mediterranean and Atlantic Spanish coast (Delgado et al. 1990, Franco et al. 1994, Frangópulos et al. 2000, Figueroa et al. 2007, Penna et al. 2008 and ICES 2011).

The haptophyte alga Prymnesium parvum N. Carter has been responsible for toxic events, with severe ecological impacts, in many parts of the world (Moestrup 1994). This organism produces a set of highly potent exotoxins, commonly called prymensins, that have been shown to have several biological effects, including ichthyotoxic, neurotoxic, cytotoxic, hepatotoxic and hemolytic activity towards a range of marine organisms (Igarashi et al. 1996, Manning and La Claire 2010). P. parvum was described for the first time in England (Carter 1937) and has been responsible for massive fish mortalities around the world (Granéli and Turner 2006, Johnsen et al. 2010).

Because of these deleterious effects, several methods for determining the toxicity of marine microalgae have been used to date. The most common is the mouse bioassay developed by the Japanese Ministry of Health and Welfare (Yasumoto et al. 1978). This method is characterized by being accurate and of short-term response, but the controversy in the use of mammals for bioassays has led to the search for and practice of new alternative bioassays (FAO 2005). In this research field, phytoplankton toxicity has been tested in marine organisms, including fish and invertebrates; the tests include mortality tests with crustaceans of the genus Artemia (Houdan et al. 2004, Zhenxing et al. 2006, Faimali et al. 2012). Moreover, toxicity of extracts from different diatoms has been evaluated in sea urchin embryos (Buttino et al. 1999, Hansen et al. 2003). It should be noted that the toxic capacity of some toxic microalgae is still unknown and that toxicity induction depending on the environmental conditions, mainly nutrient availability, has led to some controversy (Granéli and Johanson 2003, Remmel et al. 2011).

Due to the high toxicity reported for A. minutum and other dinoflagellates, its toxicity level should be fully evaluated to prevent the risk of bloom episodes in coastal areas. In addition, the involvement of the genus Prymnesium in fish mortalities makes its toxicity evaluation important in order to ensure the good quality of areas with fish aquaculture and shellfish exploitation.
Toxicity may be variable between strains of potentially toxic species (e.g. Ichimi et al. 2002, Montoya et al. 2010, Varela et al. 2012). It is therefore necessary to evaluate the toxicity of local strains of known potentially toxic species, such as Alexandrium minutum and Prymnesium parvum.

In the present study, bioassays with three different marine invertebrates (with different levels of biological organization) were applied as a detection tool to assess the toxic capacity of these marine microalgae species. A set of ecotoxicological tests was carried out to investigate the effects of $A$. minutum and P. parvum using different treatments on larvae of the sea urchin Paracentrotus lividus (Lamarck 1816), the branchiopod Artemia franciscana (Leach 1819) and adults of the amphipod Corophium multisetosum (Stock 1952).

The branchiopod A. franciscana is used routinely as a test organism for screening in ecotoxicological studies (Sorgeloos et al. 1978). Its life cycle begins with the hatching of dormant cysts that, once rehydrated in salt water, start the development as nauplii larvae, which are the material for the bioassays. These crustaceans are characterized by their adaptability to a wide range of salinity and temperature conditions: their short life cycle; their high adaptability to adverse environmental conditions; their high fecundity; their bisexual/parthenogenetic reproduction strategy (with nauplii or cysts production); their small body size; and their adaptability to variable food resources. They are also non-selective filter feeders sensitive to toxic substances (Sarabia 2002, Faimali et al. 2012).

The sea urchin Paracentrotus lividus is also used widely for testing particular contaminants (Fernández 2002) and determining phytotoxicity (Buttino et al. 1999, Hansen et al. 2003, Privitera et al. 2012). P. lividus has a wide geographic distribution, is abundant, and is easily harvested and maintained in the laboratory (Garmendia et al. 2009). Moreover, obtaining gametes and in vitro fecundation do not involve difficulties, while the embryonic development is short, thus allowing viable larvae to be obtained in a short time (Garmendia et al. 2009).

Marine and estuarine amphipods are regarded as one of the most suitable model species for integrating the effects of multiple toxic compounds (USEPA 2001, OSPAR Commision 2005). However, C. multisetosum has not been used previously for determining microalgae toxicity.

The bioassays were applied with the aim of (i) evaluating the sensitivity of the abovementioned species to the toxicity of $A$. minutum and $P$. parvum in the presence and absence of cells; and (ii) comparing the sensitivity of the three organisms to the toxicity of the mentioned phytoplankton species.

\section{MATERIALS AND METHODS}

\section{Algae species}

\section{Strains origin}

Microalgae samples were collected in the spring and summer of 2004 in the Abra of Bilbao, a bay at the sea- 


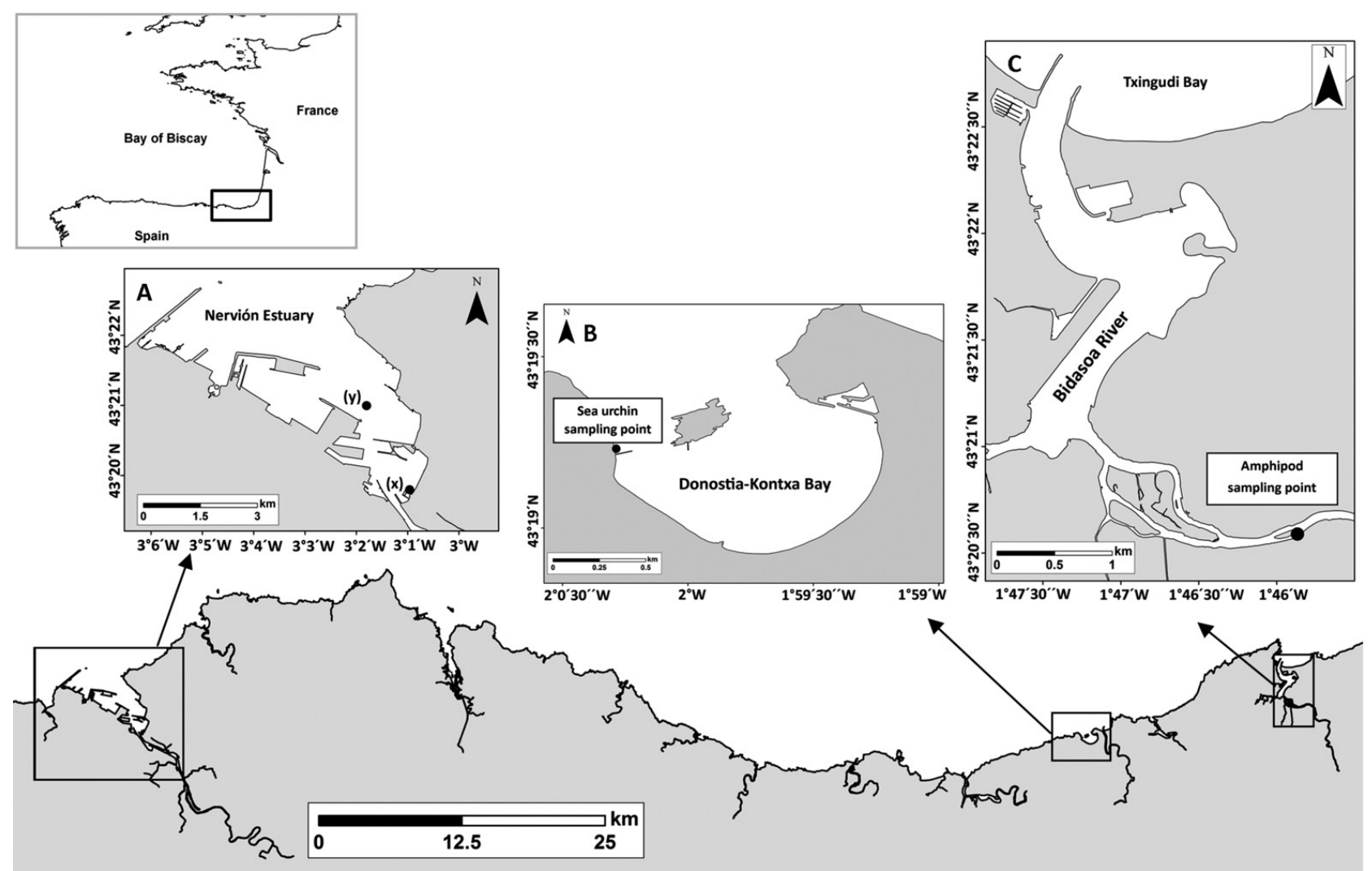

Fig. 1. - The Basque Coast, showing the sampling localities. Microalgae sampling points: A, Alexandrium minutum (x) and Prymnesium parvum (y); B, sea urchin Paracentrotus lividus; C, amphipod Corophium multisetosum.

ward end of the Nervión estuary, in the Bay of Biscay. The clonal strain Dn4EHU of Alexandrium minutum was isolated from a sample collected in May 2004 in the marina of Getxo (inner Abra of Bilbao) (Fig. 1A). For strain isolation, a single cell was captured with a glass capillary under an inverted microscope (Nikon Diaphot TMD). Before being inoculated into the culture plate, the cell was transferred to a sterile culture medium drop and captured again, to eliminate possible contaminants. For the taxonomic identification, cells were stained with calcofluor $\left(0.15 \mathrm{mg} \mathrm{mL}^{-1}\right)$ and thecal plates were observed using a LeicaTM DMRB light microscope.

The Prymnesium parvum strain (Hp13EHU) was isolated from a plankton sample collected in August 2004 in the outer Abra of Bilbao (Fig. 1A). In order to obtain unialgal cultures, serial dilution cultures were made from the field sample. Taxonomic identification was performed through cellular scale characterization, using transmission electron microscopy (Seoane et al. 2009).

\section{Culture conditions}

A. minutum and $P$. parvum were grown in $1 \mathrm{~L} \mathrm{Er-}$ lenmeyer flasks containing $0.5 \mathrm{~L}$ of culture medium and maintained at $20^{\circ} \mathrm{C}$, at an approximate irradiance of $100 \mu \mathrm{mol} \mathrm{m} \mathrm{m}^{-2} \mathrm{~s}^{-1}$ in a 14:10 light:dark period. Cultures were grown in $\mathrm{f} / 2-\mathrm{Si}$ (Guillard and Ryther 1962) prepared with filtered and autoclave-sterilized seawater. To obtain the growth curve, fluorescence was measured daily with a Turner Designs 10-100R fluorometer as a proxy of cell density. Toxicity tests were performed with both cultures $(A$. minutum and $P$. parvum) in their early stationary growth stage in order to obtain high start-point cell densities.

Before being used for toxicological testing, the cell density was determined with a Neubauer chamber. Cultures were diluted with marine filtered water $(0.22$ $\mu \mathrm{m})(\mathrm{MFW})$ to obtain different algal concentrations.

\section{Test organisms}

\section{Paracentrotus lividus}

Fourteen $P$. lividus individuals with a test diameter (excluding spines) greater than $40 \mathrm{~mm}$ were collected from a rocky shore located on the west coast of Donostia-San Sebastián (Fig. 1B) in May and June 2012. Specimens were transported alive in a container with seawater and processed immediately in the laboratory.

\section{Artemia franciscana}

Artemia franciscana tests were performed following the standard operational procedure (Artoxkit 1990). Cysts (MicroBioTests Inc., Nazareth, Belgium) were hatched in $10 \mathrm{~mL}$ of standard seawater at $25^{\circ} \mathrm{C}$ under continuous light for 30 hours. After that time, all larvae had moulted to instar II-III stages and the hatched nauplii were separated from remaining cysts using a Pasteur pipette. 


\section{Corophium multisetosum}

Six hundred specimens of $C$. multisetosum were collected from sediments of the Bidasoa estuary (Fig. 1C) in June 2012 during low tide and transported to the laboratory. Individuals were maintained for one week following the USEPA (2001) recommendations; by being placed in trays containing water with continuous aeration, at $20^{\circ} \mathrm{C}$ and a salinity of 25 with an increase of three units per day until it reached salinity of 35 .

\section{Toxicity bioassays}

The ecotoxicological tests were performed using different cell concentrations and two treatments: test organisms were exposed (i) to the microalgae culture (cells + medium) and (ii) to the medium devoid of cells after eliminating the cells by filtration in order to detect the toxicity caused by the excretion of the toxins.

The bioassays were performed on II-III stage nauplii larvae of Artemia franciscana, on newly-fertilized sea urchin embryos (Paracentrotus lividus), and on adults of the amphipod Corophium multisetosum.

In order to define the accurate microalgae concentration range of Alexandrium minutum and Prymnesium parvum for the bioassay with $P$. lividus and A. franciscana, an initial test was undertaken. The mortality observed in this initial experiment helped us to define a more precise concentration range for a definitive test (see Table 1 for concentration ranges).

\section{P. lividus: toxicity bioassay}

The procedure followed in this study to carry out the Paracentrotus lividus embryo-larval bioassay, was taken from the protocol of Garmendia et al. (2009). After equatorial dissection on the sea urchins (Fig. 2A), oocytes $(500 \mu \mathrm{L})$ were transferred to a $100-\mathrm{mL}$ flask filled previously with MFW, and a small quantity of sperms was then added. After 5-10 min, egg density and fecundation success were determined by taking four $20-\mu \mathrm{L}$ replicates and counting the total eggs in the aforementioned volume and the number of eggs that contained the fertilization membrane (Fig. 2B). A minimum fecundation success of $90 \%$ was established as being indicative of the good quality of the model organisms (Garmendia et al. 2009).

The bioassay was based on the exposure of the newly-fertilized eggs to different concentrations of cultured and filtered microalgae for 48 hours (Table 1).
After fertilization, approximately 500 eggs were transferred to propylene glasses (6 replicates for each algae concentration and 11 for the control, following Garmendia et al. [2009] and Beiras et al. [2002]) containing $20 \mathrm{~mL}$ of toxic algae solution or MFW. The glasses were covered and stored in the incubation camera in darkness for 48 hours at $20^{\circ} \mathrm{C}$. After incubation, one replicate per treatment was used to measure oxygen, salinity and temperature in order to ensure normal optimal conditions. In the remainder of the replicates, $40 \%$ formaldehyde was added to arrest larva development. Embryonic success was estimated by counting the normal pluteus larvae among the 100 first larvae observed. Larvae were considered normal when the four arms were correctly formed (Garmendia et al. 2009) (Fig. 2C). On the other hand, larvae were considered non-well-developed when no four arms were formed (Fig. 2D). To consider the test as valid, the embryo success in the control must be higher than $90 \%$ (Fernández 2002). A negative control was performed with the nontoxic algae Isochrysis galbana (strain Hp1EHU).

\section{A. franciscana: toxicity bioassay}

The toxicity tests were performed in 24-well polystyrene multiwell plates containing $1 \mathrm{~mL}$ of different cell concentrations (Table 1). Marine standard water was used as a control and I. galbana as a negative control. Ten nauplii larvae were transferred to each well and the multiwell plates were covered with a parafilm and stored at $20^{\circ} \mathrm{C}$ in darkness for 48 hours. After 24 and 48 hours, dead larvae were counted. Larvae were considered dead when no movement was detected after 10 seconds of observation and semi-dead when the movement had decreased compared with the nonaffected larvae. To consider the test as valid, the mortality in the control must be lower than $10 \%$ (Artoxkit 1990). Dead larvae were observed under the microscope in order to determine the presence or absence of algae cells inside the digestive system.

\section{C. multisetosum: toxicity bioassay}

The experiment was based on the exposure of adult amphipods to different concentrations of A. minutum and $P$. parvum (Table 1$)$. Ten amphipods were placed in the glass flasks containing $100 \mathrm{~mL}$ of different microalgae concentrations. Three replicates were prepared for each concentration. Flasks were stored in the incubation cabinet in darkness for 72 hours at $20^{\circ} \mathrm{C}$. After that time,

Table 1. - Alexandrium minutum and Prymnesium parvum concentration ranges in the different bioassays.

\begin{tabular}{llll}
\hline Algae species & Test organism & Bioassay & \multicolumn{1}{c}{ Concentration $\left(\right.$ cells mL $\left.^{-1}\right)$} \\
\hline Alexandrium minutum & P. lividus & Initial test & $0 ; 100 ; 500 ; 1000 ; 5000 ; 50000 ; 100000$ \\
& Artemia sp. & Definitive test & $0 ; 50000 ; 60000 ; 75000 ; 90000 ; 100000$ \\
& Initial test & $0 ; 100 ; 500 ; 1000 ; 5000 ; 50000 ; 100000$ \\
& C. multisetosum & Definitive test & $0 ; 1000 ; 5000 ; 10000 ; 50000 ; 100000$ \\
Prymnesium parvum & P. lividus & Initial test & $0 ; 40000 ; 60000 ; 75000 ; 100000$ \\
& Artemia sp. & Definitive test & $0 ; 1000 ; 5000 ; 10000 ; 100000 ; 230000 ; 150000 ; 180000 ; 200000 ; 250000 ; 300000$ \\
& C. multisetosum & Initial test & $0 ; 1000 ; 5000 ; 10000 ; 100000 ; 230000$ \\
& & Definitive test & $0 ; 5000 ; 10000 ; 100000 ; 200000 ; 250000$ \\
& & $0 ; 50000 ; 100000 ; 150000 ; 205000$ \\
\hline
\end{tabular}



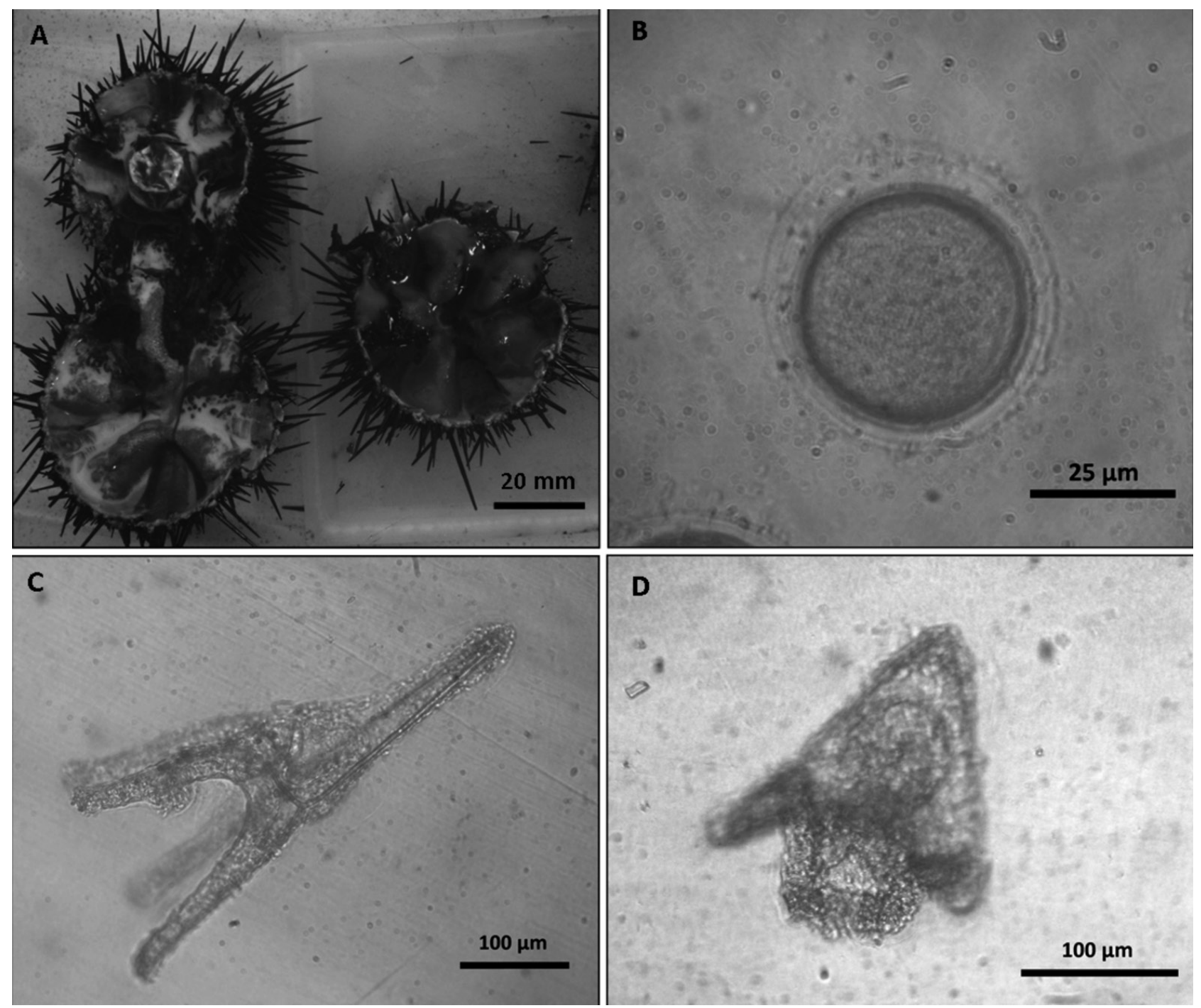

Fig. 2. - Paracentrotus lividus bioassay. A, equatorial dissection of the sea urchin before fertilization; B, oocyte with the fertilization membrane after fertilization; $\mathrm{C}$, sea urchin larva completely developed with the four arms correctly separate; D, poorly developed sea urchin larva resulting after exposure to toxic sample.

amphipods were considered dead when no movements were registered within 60 seconds. To consider the test as valid, the mortality in the control must not be higher than $10 \%$ (Casado-Martínez et al. 2006).

\section{Reference toxicant tests}

The quality and sensitivity of the model organisms used in the different bioassays was evaluated by the use of reference substances. Sodium dodecyl sulphate (SDS) was used in a range from 2 to $8 \mathrm{mg} \mathrm{L}^{-1}$ for $P$. lividus and ammonium in a range from 4 to $128 \mathrm{mg} \mathrm{L}^{-1}$ for C. multisetosum.

\section{Statistical analysis}

The $\mathrm{LC}_{50}$ and $\mathrm{LC}_{10}$ values (the concentrations causing, respectively, 50 and $10 \%$ mortality or non-normal development), together with their $95 \%$ confidence intervals were calculated by fitting the survival data to a regression curve by a Probit analysis (Fernández 2002), with the statistical package Statgraphics ${ }^{\circledR}$ Plus 5.0. The "goodness of fit" was checked using the $\chi^{2}$ test. Following the methodology described by the United States Environmental Protection Agency (USEPA 2002), when data did not fit Probit requirements (normality and homoscedasticity) a graphical method was used to determine $\mathrm{LC}_{50}$ value.

Following Pérez and Beiras (2010), the NOEC (no effective observed concentration) and LOEC (low effective concentration) values were calculated with the Kruskal-Wallis and the Mann-Whitney U non-parametric test. Differences were considered as significant when $\mathrm{p}$ was lower than 0.05 .

\section{RESULTS}

The abiotic parameters in all microalgae culture flasks (oxygen, salinity and temperature) are reported in Table 2. The $\mathrm{LC}_{10}$ and $\mathrm{LC}_{50}$ values for SDS in $P$. lividus and the $\mathrm{LC}_{50}$ value for $\mathrm{NH}_{4}{ }^{+}$in Corophium are reported in Table 3 . 
Table 2. - Physico-chemical parameters measured in flasks of the different microalgae cultures.

\begin{tabular}{lcccc}
\hline \multicolumn{1}{c}{ Species } & Experiment & Oxygen $(\%)$ & Salinity & Temperature $\left({ }^{\circ} \mathrm{C}\right)$ \\
\hline Isochrysis galbana & Negative control test $P$. lividus & 119 & - & - \\
Isochrysis galbana & Negative control test Artemia & 113.5 & 33.1 & 23.6 \\
Alexandrium minutum & Initial test & 100.3 & 35.1 & 20.4 \\
Prymnesium parvum & Initial test & 101 & 35.4 & 21 \\
Alexandrium minutum & Definitive test & 92.7 & 34.6 & 21.2 \\
Prymnesium parvum & Definitive test & 92.8 & 35.4 & 21 \\
\hline
\end{tabular}

Table 3. - Lethal concentration (mg L-1) for SDS in Paracentrotus lividus and for $\mathrm{NH}_{4}{ }^{+}$in Corophium multisetosum, their respective confidence intervals $(95 \%)$ and NOEC $\left(\mathrm{mg} \mathrm{L}^{-1}\right)$ and LOEC $\left(\mathrm{mg} \mathrm{L}^{-1}\right)$ values.

\begin{tabular}{|c|c|c|c|c|c|c|c|}
\hline $\begin{array}{l}\text { Toxicant } \\
\text { reference }\end{array}$ & Test organism & Bioassay & $\begin{array}{c}\mathrm{LC}_{10} \\
\left(\mathrm{mg} \mathrm{L}^{-1}\right)\end{array}$ & $\begin{array}{c}\mathrm{LC}_{50} \\
\left(\mathrm{mg} \mathrm{L}^{-1}\right)\end{array}$ & $\begin{array}{c}\text { NOEC } \\
\left(\mathrm{mg} \mathrm{L}^{-1}\right)\end{array}$ & $\begin{array}{c}\text { LOEC } \\
\left(\mathrm{mg} \mathrm{L}^{-1}\right)\end{array}$ & Reference \\
\hline \multirow[t]{2}{*}{ SDS } & \multirow[t]{2}{*}{ Paracentrotus lividus } & Initial test & $\begin{array}{c}3.02 \\
(2.91-3.12)\end{array}$ & $\begin{array}{c}4.05 \\
(3.98-4.11)\end{array}$ & 2.1 & 3.15 & Present study \\
\hline & & $\begin{array}{c}\text { Definitive } \\
\text { test }\end{array}$ & $\begin{array}{c}1.99 \\
(1.91-2.06) \\
-\end{array}$ & $\begin{array}{c}2.65 \\
(2.61-2.70) \\
3.95 \\
(3.34-4.56)\end{array}$ & - & $\begin{array}{c}2.03 \\
-\end{array}$ & $\begin{array}{l}\text { Present study } \\
\text { Menchaca } 2010\end{array}$ \\
\hline $\mathrm{NH}_{4}^{+}$ & Corophium multisetosum & & - & $\begin{array}{c}25.47 \\
(20.98-31.15) \\
55 \\
(26-114.9)\end{array}$ & $\begin{array}{l}8 \\
-\end{array}$ & $\begin{array}{l}16 \\
-\end{array}$ & $\begin{array}{c}\text { Present study } \\
\text { Pérez } 2006\end{array}$ \\
\hline
\end{tabular}

The $\mathrm{LC}_{50}-\mathrm{SDS}$ for $P$. lividus in the initial test was $4.05 \mathrm{mg} \mathrm{L}^{-1}$; it was $2.65 \mathrm{mg} \mathrm{L}^{-1}$ in the definitive test. Furthermore, NOEC and LOEC values for the initial test were 2.1 and $3.15 \mathrm{mg} \mathrm{L}^{-1}$, respectively. LOEC for the definitive test was $2.03 \mathrm{mg} \mathrm{L}^{-1}$ (Table 3). The $\mathrm{LC}_{50^{-}}$ $\mathrm{NH}_{4}{ }^{+}$for $C$. multisetosum was $25.47 \mathrm{mg} \mathrm{L}^{-1}$. Moreover, NOEC and LOEC values were 8 and $16 \mathrm{mg} \mathrm{L}^{-1}$, respectively.

\section{Paracentrotus lividus bioassay}

The highest concentration of the dinoflagellate, 100000 cell $\mathrm{mL}^{-1}$, caused the inhibition of the embryonic development in all of the sea urchin larvae while from the lowest concentration tested $\left(100\right.$ cell $\mathrm{mL}^{-1}$, to 1000 cell $\mathrm{mL}^{-1}$ ) no significant differences from the control were detected (Fig. 3A). A toxic effect was observed at

\section{Paracentrotus lividus}
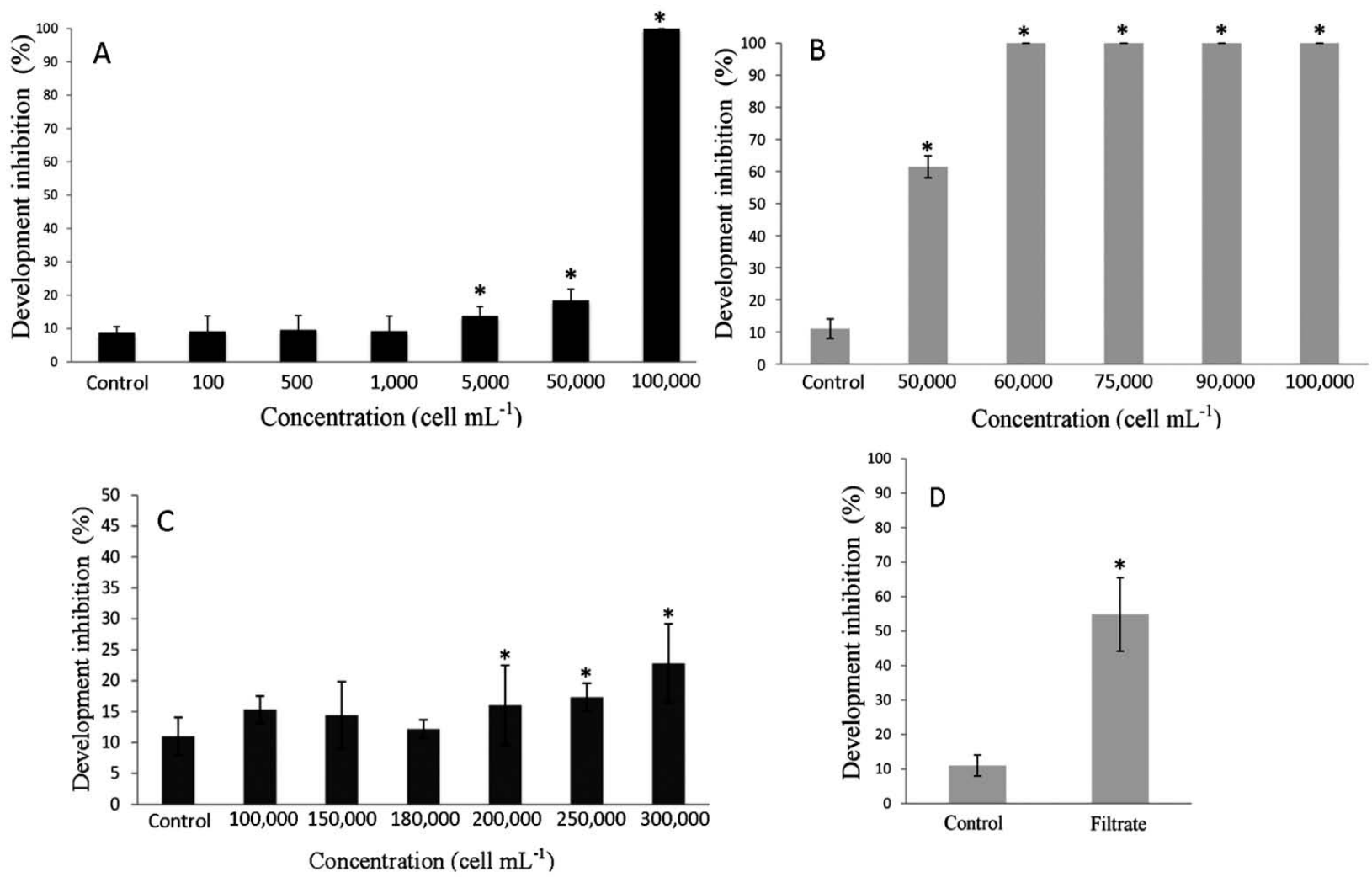

Fig. 3. - Percentage of Paracentrotus lividus embryonic development inhibition as a function of algal cell concentration with standard error of the mean for Alexandrium minutum culture of the initial (A) and definitive (B) tests and for Prymensium parvum culture (C) and filtrate (D). *: Significant differences $(\mathrm{p}<0.05)$. 
Table 4. - Lethal concentration $\left(\mathrm{mg} \mathrm{L}^{-1}\right)$ for Alexandrium minutum and Primnesium parvum $\left(\mathrm{LC}_{10}\right.$ and $\left.\mathrm{LC}_{50}\right)$ and their respective confidence intervals (95\%), NOEC $\left(\mathrm{mg} \mathrm{L}^{-1}\right)$ and LOEC $\left(\mathrm{mg} \mathrm{L}^{-1}\right)$ values.

\begin{tabular}{|c|c|c|c|c|c|c|c|}
\hline $\begin{array}{l}\text { Algae } \\
\text { species }\end{array}$ & Test organism & Bioassay & $\begin{array}{c}\mathrm{LC} 10 \\
\left(\text { cell } \mathrm{mL}^{-1}\right)\end{array}$ & $\begin{array}{c}\mathrm{LC50} \\
\left(\text { cell } \mathrm{mL}^{-1}\right) \\
\end{array}$ & $\begin{array}{c}\text { NOEC } \\
\left(\text { cell } \mathrm{mL}^{-1}\right) \\
\end{array}$ & $\begin{array}{c}\text { LOEC } \\
\left(\text { cell } \mathrm{mL}^{-1}\right)\end{array}$ & Reference \\
\hline \multirow[t]{7}{*}{ A. minutum } & P. lividus & Initial test & - & 65381 & 1000 & 5000 & Present study \\
\hline & & Definitive test & - & $<50000$ & - & 50000 & Present study \\
\hline & Artemia sp. & $24 \mathrm{~h}$ & - & 150629 & 1000 & 5000 & Present study \\
\hline & & & & (83816 - ) & & & \\
\hline & & $48 \mathrm{~h}$ & $\begin{array}{c}645 \\
(1072-16596)\end{array}$ & $\begin{array}{c}16218 \\
(93326-301995)\end{array}$ & 1000 & 5000 & Present study \\
\hline & & & & & & 2000 & Zhenxing et al. 2006 \\
\hline & C. multisetosum & & - & - & 100000 & - & Present study \\
\hline \multirow[t]{9}{*}{ P. parvum } & P. lividus & Initial test & - & - & 100000 & 230000 & Present study \\
\hline & & Definitive test & - & - & 180000 & 200000 & Present study \\
\hline & S. granularis & & - & $3-400000$ & - & - & Hansen et al. 2003 \\
\hline & Artemia sp. & $24 \mathrm{~h}$ & - & - & 250000 & - & Present study \\
\hline & & $48 \mathrm{~h}$ & - & - & 250000 & - & Present study \\
\hline & & $24 \mathrm{~h}$ & - & 500000 & - & - & Houdan et al. 2004 \\
\hline & & $48 \mathrm{~h}$ & - & $<100000$ & - & - & \\
\hline & & & - & 26500 & - & - & Granéli and Johansson 2003 \\
\hline & C. multisetosum & - & - & - & 205000 & - & Present study \\
\hline
\end{tabular}

5000 cell $\mathrm{mL}^{-1}$, with approximately $15 \%$ of embryonic inhibition. At 50000 cell $\mathrm{mL}^{-1}$ the inhibition reached $20 \%$. Considering these observations, a new range was applied in a definitive test: from 50000, to 100000 cell $\mathrm{mL}^{-1}$ (Table 1). The results showed a marked toxic effect at 50000 cell $\mathrm{mL}^{-1}$, while $100 \%$ of inhibition was achieved above 60000 cell $\mathrm{mL}^{-1}$ (Fig. 3B). For the initial and definitive tests, LOEC values were 5000 and 50000 cell $\mathrm{mL}^{-1}$, respectively (Table 4$)$. On the other hand, the filtrate of A. minutum at the maximum concentration did not show any toxic effect on the sea urchin's embryonic development (data not shown).

For the initial test of Prymnesium parvum, significant differences from the control in the development inhibition of sea urchin larvae $(\mathrm{p}<0.05)$ were observed in a concentration of 230000 cell $\mathrm{mL}^{-1}$. For the definitive test, the concentration range was established at between 100000 and 300000 cell $\mathrm{mL}^{-1}$. From 100000 to 180000 cell $\mathrm{mL}^{-1}$, development inhibition was similar to the control (Fig. 3C); at and above $200000 \mathrm{cell} \mathrm{mL}^{-1}$, significant differences from the control were observed $(\mathrm{p}<0.05)$. The highest development inhibition was reached at 300000 cell $\mathrm{mL}^{-1}(22.8 \%)$, so $\mathrm{LC}_{50}$ could not be calculated. NOEC and LOEC values were 180000 and 200000 cell $\mathrm{mL}^{-1}$, respectively (Table 4). Considering the filtrate of $P$. parvum, inhibition of more than $50 \%$ of embryo development was obtained at a concentration of 300000 cell $\mathrm{mL}^{-1}$, showing significant differences from the control sample $(\mathrm{p}<0.05)$ (Fig. 3D).

\section{Artemia franciscana bioassay}

The mortality of the $15 \%$ of nauplii population was induced at a concentration of 5000 cells $\mathrm{mL}^{-1}$ of the dinoflagellate A. minutum after 24 hours of exposure; however, $50 \%$ of mortality was not achieved with the initial concentrations. Higher cell densities were therefore used to perform the definitive bioassay (Table 1). In addition, the exposure time was increased from 24 to 48 hours. Incubation with the dinoflagellate significantly affected nauplii mortality during both exposure periods $(p<0.05)$. After 24 hours of exposure, significant differences from the control were observed from

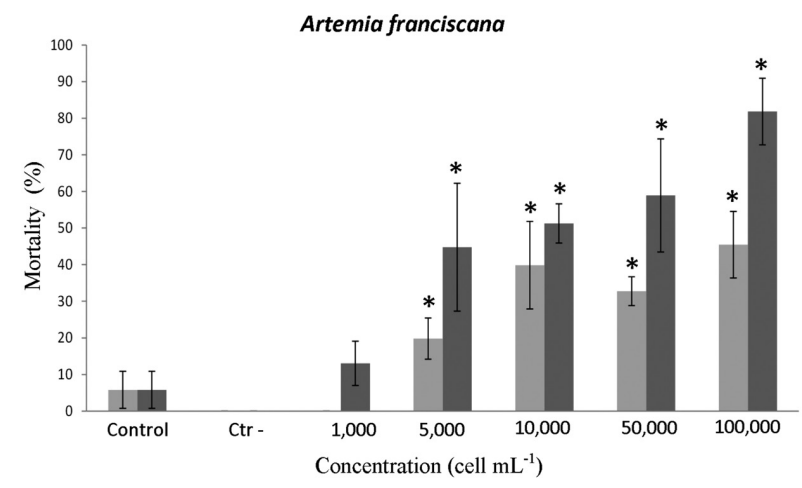

Fig. 4. - Mortality after $24 \mathrm{~h}$ (dark grey bar) and $48 \mathrm{~h}$ (light grey bar) of nauplii larvae of Artemia franciscana exposed to Alexandrium minutum culture. Two controls were used: standard seawater $(0.22$ $\mu \mathrm{m})$ and Isochrysis galbana as a negative control. * significant differences $(\mathrm{p}<0.05)$.

5000 cell $\mathrm{mL}^{-1}(19 \%$ of mortality) $(\mathrm{p}<0.05)$, increasing with the concentration until $45 \%$ mortality at 100000 cell $\mathrm{mL}^{-1}$ (Fig. 4). After 48 hours, at 50000 and 100000 cell $\mathrm{mL}^{-1}$, the mortality in the nauplii population was $58 \%$ and $81 \%$, respectively. The effect of exposure time can be observed with $\mathrm{LC}_{50}$ values at 24 and $48 \mathrm{~h}$ : 150629 and 16218 cell $\mathrm{mL}^{-1}$, respectively (Table 4). In addition, the minimum concentration with significant mortality was 5000 cell $\mathrm{mL}^{-1}$ at 24 and 48 hours of exposure. Related to the filtrate of A. minutum, the maximum algae concentration (100000 cell $\left.\mathrm{mL}^{-1}\right)$ showed no significant differences from the control sample ( $>0.05$ ) (data not shown). On the other hand, A. franciscana nauplii survival was not affected by the presence of Prymnesium parvum cells or filtrate at maximum exposure concentration, i.e. 250000 cell $\mathrm{mL}^{-1}(\mathrm{p}>0.05)$ (data not shown). However, a sub-lethal effect was detected along the concentration gradient, i.e. the movement of the nauplii was reduced at maximum exposure concentration $\left(250000\right.$ cell $\left.\mathrm{mL}^{-1}\right)$, without reaching a mortality effect.

Due to logistic difficulties, the presence of cell content inside the alimentary canal of A. franciscana could not be identified. 


\section{Corophium multisetosum}
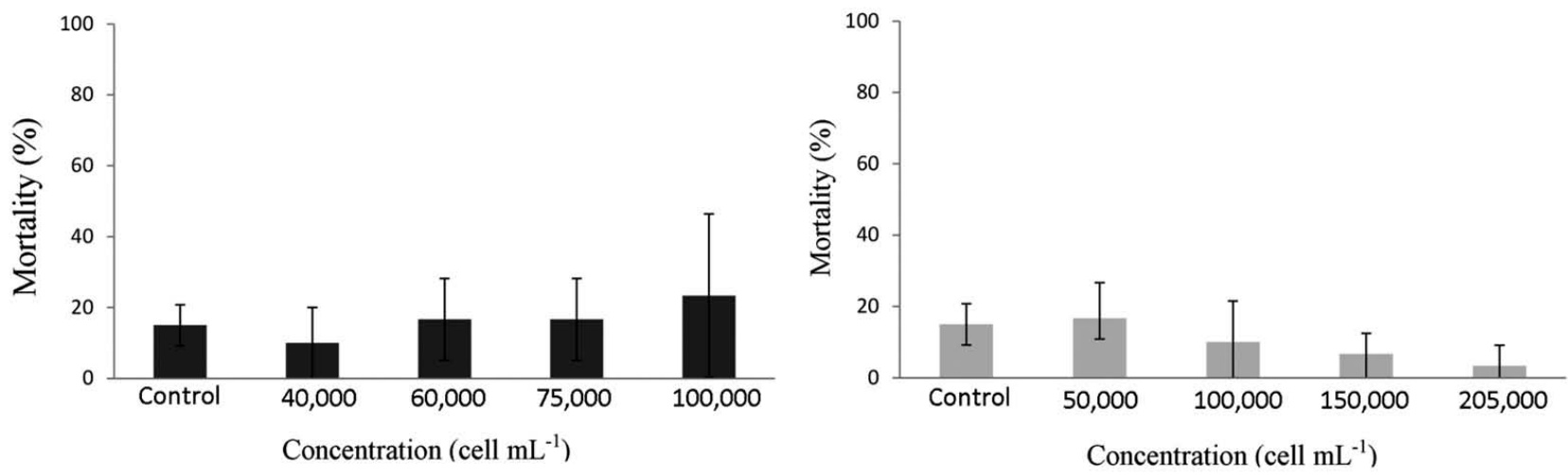

Fig. 5. - Mortality after $72 \mathrm{~h}$ of Corophium multisetosum exposed to culture of Alexandrium minutum (left) and Prymnesium parvum (right). No significant differences in mortality between control and samples were observed.

\section{Corophium multisetosum bioassay}

In relation to $C$. multisetosum mortality results, after 72 hours of exposure to both microalgae, significant differences from the control were not observed for any concentration $(\mathrm{p}>0.05)$. However, an increase in mortality was observed throughout the concentration range of Alexandrium minutum (Fig. 5).

\section{DISCUSSION}

Lethal concentrations $\left(\mathrm{mg} \mathrm{L}^{-1}\right)$ for SDS in P. lividus and for $\mathrm{NH}_{4}{ }^{+}$in C. multisetosum, as calculated in this study, lie within the range of those obtained previously by Menchaca (2010) and Pérez (2006), respectively (Table 3). Our results have therefore confirmed the good quality of the model organisms (differences in the quality of gonad material were observed in the two different periods where sea urchins were collected, as the $\mathrm{LC}_{50}$ value for SDS in P. lividus obtained in May (the initial test) was higher than the value obtained in June (the definitive test). This observation is in accordance with Garmendia et al. (2010), who also detected variability in the quality of the gonad material throughout the year. Therefore, this assumption must be considered when interpreting the differences found in results of the two sets of trials performed with $P$. lividus exposed to A. minutum.

The dinoflagellate Alexandrium minutum was toxic for $A$. franciscana nauplii at 5000 cell $\mathrm{mL}^{-1}$, while the $\mathrm{LC}_{50}$ value increased with exposure time. The 48-hour exposure proved to be much more harmful, indicating that both concentration and exposure time contributed to the toxic response in the nauplii population. The toxic effect of A. minutum on A. franciscana nauplii survival has rarely been examined. Our results agree with those of Zhenxing et al. (2006), who found that four strains of Alexandrium spp. were lethal for A. sali$n a$ at a density of 2000 cell $\mathrm{mL}^{-1}$. Regarding the filtrate of A. minutum, the maximum concentration (100000 cell $\mathrm{mL}^{-1}$ ) showed no toxic effect in the $A$. franciscana nauplii, which is explained by the fact that their toxicity is linked to the intact cell, as has been reported for Ostreopsis cf. ovata (Faimali et al. 2012)
In contrast, $A$. franciscana nauplii survival was not affected by the presence of $P$. parvum culture or filtrate at the maximum exposure concentration (250000 cell $\mathrm{mL}^{-1}$ ). These results contrast with those of Houdan et al. (2004), who found an $\mathrm{LC}_{50}$ value of a $P$. parvum culture (in the stationary phase) lower than 100000 cell $\mathrm{mL}^{-1}$ for A. salina. Some authors have suggested that this sensitivity disagreement could be related to differences in microalgae culture conditions (Granéli and Johanson 2003). According to the aforementioned authors, excretion of toxic metabolites might be a general mechanism among toxic haptophytes when exposed to stress events, e.g. nutrient-deficient conditions. However, recent studies hypothesize that the majority of Prymnesium toxicity is cellular-based rather than related to exotoxins production (Remmel et al. 2011). Further, reduction of $A$. franciscana movement with exposure time, as shown in the present study at the maximum exposure concentration of $P$. parvum, is in accordance with the results of Remmel and Hambright (2012). These investigators observed that Prymensium cells were attached to most exterior surfaces, to fish gills and to feeding and respiratory appendages in zooplankton, which contributed to the movement depletion of individuals. Moreover, they found that the number of attached cells increased with exposure time and density of Prymnesium.

The toxicity of $A$. minutum and $P$. parvum had not been evaluated previously using sea urchin embryo bioassays. However, a dose-dependent toxic effect of several marine microalgae on sea urchin cell division has been recorded in several studies (Paul and Fenical 1984, Lemée et al. 1993, Pedrotti et al. 1996, Buttino et al. 1999). In the present study, A. minutum was toxic to sea urchin embryos at 5000 cell $\mathrm{mL}^{-1}$ (LOEC value). These results are in accordance with those of Privitera et al. (2012), who demonstrated the toxic effect in competent sea urchin larvae when exposed to the dinoflagellate Ostreopsis cf. ovata. On the other hand, filtrate of the dinoflagellate showed no toxic effect on the development of the sea urchin. This scenario is also in agreement with Faimali et al. (2012), who demonstrated that dinoflagellates do not show significant toxicity with growth medium devoid of cells. 
By contrast, the culture and filtrate of $P$. parvum significantly inhibited embryo development at 200000 and 300000 cell $\mathrm{mL}^{-1}$. These effective concentrations are within the range of those calculated by Hansen et al. (2003), who reported a cell division reduction of newly-fertilizing eggs of the sea urchin Sphaerechinus granularis exposed to a haptophyte. However, Remmel and Hambright (2012) suggested that the presence of toxins in the filtrate could be an artefact caused by the vacuum pressure used in the filtration process, which can cause cell disruption and the subsequent release of intracellular toxins. The result of the filtrate reported in the present study should therefore be considered carefully.

In the present study, adult amphipods were not sensitive to the toxicity of $A$. minutum and $P$. parvum at the concentrations tested. This finding contrasts with those of other authors who have routinely used adult zooplankton organisms (Euterpina acutifrons and Acartia grani) to evaluate the toxicity of A. minutum (Frangópulos et al. 2000, Costa and Fernández 2002). However, Romano et al. (2003) observed that secondary metabolites, such as unsaturated aldehydes produced by some algae during stress events, such as depredation (Pohnert 2000), were not toxic in adult copepods, while they inhibited the development of oocytes and embryos. Romano et al. (2003) hypothesized that this behaviour could be a defence mechanism of microalgae, designed to regulate the populations of herbivorous zooplankton.

Assuming similar test conditions (photoperiod, temperature, salinity and oxygen) for all the bioassays performed, among the tested organisms A. franciscana nauplii showed the highest sensitivity for Alexandrium minutum according to $\mathrm{LC}_{50}-48 \mathrm{~h}$. These results are in agreement with those of Faimali et al. (2012) and Privitera et al. (2012), who suggested that the development stages could affect the sensitivity of the organisms, increasing the mortality with the ingestion rate. Moreover, Zhenxing et al. (2006) confirmed a decrease in the survival of Artemia salina nauplii with the feeding rates of Alexandrium spp. However, in the present study, owing to logistic difficulties, the presence of cell content inside the alimentary canal of A. franciscana could not be identified. As a result, it cannot be concluded that the higher sensitivity of A. franciscana nauplii is related to the ingestion of the microalgae. In the case of $P$. parvum, difficulties in the $\mathrm{LC}_{50}$ calculation did not permit comparison of the sensitivity between the tested organisms.

The presence of toxic microalgae on the coasts of the Basque Country is monitored every year, within the context of the EU Water Framework Directive (WFD) (e.g. Borja et al. 2009). In 2008 the cell density of Alexandrium minutum was lower than 100 cell $\mathrm{L}^{-1}$, much less than the value considered as a limit for toxicity risk found in the present study. Prymnesium parvum has not been reported specifically in the WFD reports. The inverted light-microscope technique based upon fixed samples used in this monitoring programme for phytoplankton identification and counting does not usually allow species or even genus-level identification, of small naked flagellates such us Prymnesium spp. The species level identification of prymnesiophyceans requires the analysis of the body scales through electron microscopy (Seoane et al. 2009) or molecular methods.

Regarding toxicity of Alexandrium minutum, it must be considered that the long culture maintenance of the dinoflagellate in the present work may have led to the decrease in toxin production. Martins et al. (2004) demonstrated that saxitoxin production is not a constitutive, stable characteristic of Alexandrium, but can be lost during routine culture maintenance over a prolonged interval.

\section{CONCLUSION}

Only larvae of Paracentrotus lividus and Artemia franciscana have been demonstrated to be sensitive to the toxicity of the two marine microalgae Alexandrium minutum and Prymnesium parvum. The algae strains tested were isolated much in advance compared with the performed test. Therefore, the minimum toxic concentration values established in the present study for the model organisms cannot be considered as a real toxic value. We suggest performing the bioassays of the present study with the model organisms, using recent isolated $A$. minutum or $P$. parvum during toxic blooms and combining different parameters (nutrients, light and temperature) to study the potential toxicity in different conditions. Nevertheless, our results place $P$. lividus and A. franciscana bioassays as a viable alternative for the detection of $A$. minutum and $P$. parvum toxicity in the context of routine monitoring. Other standardized toxicological assays using more distant taxonomic groups are also available and have been applied extensively (Ribo and Kaiser 1987, Zon and Peterson 2005). Therefore, besides working on the use of the bioassays described in the present work, we also suggest the use of alternative methodologies in order to explore a wider range of tests for the detection of toxic events.

\section{ACKNOWLEDGEMENTS}

This paper constitutes part of the master's thesis of E. Aylagas. We wish to thank Professor Michael Collins from the School of Ocean and Earth Science of the University of Southampton (UK) and Dr. Ángel Borja from AZTI-Tecnalia (Spain) for kindly advising us on some details of the manuscript. This paper is contribution number 661 from AZTI-Tecnalia (Marine Research Unit).

\section{REFERENCES}

Anderson D.M., Alpermann T.J., Cembella A.D. et al. 2012. The globally distributed genus Alexandrium: multifaceted roles in marine ecosystems and impacts on human health. Harmful Algae 14: $10-35$

http://dx.doi.org/10.1016/j.hal.2011.10.012

Artoxkit M. 1990. Artemia toxicity screening test for estuarine and marine waters. Standard operational procedure, Creasel, Deinze, Belgium.

Beiras R. 2002. Comparison of methods to obtain a liquid phase in marine sediment toxicity bioassays with Paracentrotus lividus 
sea urchin embryos. Arch. Environ. Con. Tox. 42: 23-28. http://dx.doi.org/10.1007/s002440010287

Borja A., Bald J., Franco J. et al. 2009. Using multiple ecosystem components, in assessing ecological status in Spanish (Basque Country) Atlantic marine waters. Mar. Pollut. Bull. 59: 54-64. http://dx.doi.org/10.1016/j.marpolbul.2008.11.010

Buttino I., Miralto A., Ianora A. et al. 1999. Water-soluble extracts of the diatom Thalassiosira rotula induce aberrations in embryonic tubulin organisation of the sea urchin Paracentrotus lividus. Mar. Biol. 134: 147-154. http://dx.doi.org/10.1007/s002270050533

Carter N. 1937. New or interesting algae from brackish water. Arch. Protistenkd. 90: 1-68.

Casado-Martínez M.C., Beiras R., Belzunce M.J et al. 2006. Ejercicio interlaboratorio de bioensayos marinos para la evaluación de la calidad ambiental de sedimentos costeros. IV. Ensayo de toxicidad sobre sedimento con crustáceos anfípodos. Cienc. Mar. 32: 149-157.

Costa R.M., Fernández F. 2002. Feeding and survival rates of the copepods Euterpina acutifrons Dana and Acartia grani Sars on the dinoflagellates Alexandrium minutum Balech and Gyrodinium corsicum Paulmier and the Chryptophyta Rhodomonas baltica Karsten. J. Exp. Mar. Biol. Ecol. 273: 131-142. http://dx.doi.org/10.1016/S0022-0981(02)00132-6

Delgado M., Estrada M.J., Camp J.V. et al. 1990. Development of a toxic Alexandrium minutum Halim (Dinophyceae) bloom in the harbour of Sant Carles de la Rápita (Ebro Delta, northwestern Mediterranean). Sci. Mar. 54: 1-7.

Faimali M., Giussani V., Piazza V. et al. 2012. Toxic effects of harmful benthic dinoflagellate Ostreopsis ovata on invertebrate and vertebrate marine organisms. Mar. Environ. Res. 76: 97-107. http://dx.doi.org/10.1016/j.marenvres.2011.09.010

FAO 2005. Biotoxinas marinas. Estudio FAO: Alimentación y Nutrición. Organización de las Naciones Unidas para la Agricultura y la Alimentación. Roma, Italy, 278 pp.

Fernández N. 2002. Evaluación biológica de la contaminación marina costera mediante bioensayos con embriones del erizo de mar Paracentrotus lividus. PhD thesis, University of Vigo, $211 \mathrm{pp}$.

Figueroa R.I., Garcés E., Bravo I. 2007. Comparative study of the life cycles of Alexandrium tamatum and Alexandrium minutum (Gonyaulacales, Dinophyceae) in culture. J. Phycol. 43: 1039-1053. http://dx.doi.org/10.1111/j.1529-8817.2007.00393.x

Franco J.M., Fernández P., Reguera B. 1994. Toxin profiles of natural populations and cultures of Alexandrium minutum Halim from Galician (Spain) coastal waters. J. Appl. Phycol. 6: $275-279$. http://dx.doi.org/10.1007/BF02181938

Frangópulos M., Guisande C., Maneiro I. et al. 2000. Short-term and long-term effects of the toxic dinoflagellate Alexandrium minutum on the copepod Acartia clausi. Mar. Ecol.-Prog. Ser. 203: $161-169$ http://dx.doi.org/10.3354/meps203161

Garcés E., Camp J. 2011. Habitat changes in the Mediterranean Sea and the consequences for Harmful Algal Blooms formation. In: N. Stambler (ed.), Life in the Mediterranean Sea: A look at habitat changes. Nova Science Publishers, Inc. New York, US, ISBN: 978-1-61209-644-5, pp. 519-541.

Garmendia J.M, Menchaca I., Belzunce M.J. et al. 2009. Protocolo del test de toxicidad de sedimentos marinos con larvas del erizo de mar Paracentrotus lividus (Lamarck, 1816). RIM. 11-25.

Garmendia J.M., Menchaca I., Belzunce M.J. et al. 2010. Seasonal variability in gonad development in the sea urchin (Paracentrotus lividus) on the Basque coast (southeastern Bay of Biscay). Mar. Pollut. Bull. 61: 259-266. http://dx.doi.org/10.1016/j.marpolbul.2010.02.023

GEOHAB 2001. Global Ecology and Oceanography of Harmful Algal Blooms, Science Plan. P. Gilbert, G. Pitcher (eds), SCOR and IOC, Baltimore and Paris, $87 \mathrm{pp}$.

GEOHAB 2012. Global Ecology and Oceanography of Harmful Algal Blooms, Science Plan. Berdalet E., Tester P., Zingone A. (eds), IOC of UNESCO and SCOR, Paris and Newark, 64 pp.

Granéli E., Johansson N. 2003. Increase in the production of allelopathic substances by Prymnesium parvum cells grown under $\mathrm{N}$ or P-deficient conditions. Harmful Algae 2: 135-145. http://dx.doi.org/10.1016/S1568-9883(03)00006-4

Granéli E., Turner J.T. (eds) 2006. Ecology of Harmful Algae. Ecol. Stud. 189, Springer. 270 pp.

Guillard R.R.L., Ryther J.H. 1962. Studies of marine planktonic diatoms. I. Cyclotella nana Hustedt, and Detonula confervacea
(Cleve) Gran. Can. J. Microbiol. 8: 229-239. http://dx.doi.org/10.1139/m62-029

Halim Y. 1960. Alexandrium minutum, n. gen. n. sp. dinoflagellé provocant des "eaux rouges". Vie Milieu 11: 102-105.

Hansen, E., Eilertsen H.C., Ernstsen A et al 2003. Anti-mitotic activity towards sea urchin embryos in extracts from the marine haptophycean Phaeocystis pouchetii (Hariot) Lagerheim collected along the coast of northern Norway. Toxicon. 41: 803-812.

http://dx.doi.org/10.1016/S0041-0101(03)00034-5

Houdan A., Bonnard A., Fresnel, J. et al. 2004. Toxicity of coastal coccolithophores (Prymnesiophyceae, Haptophyta). J. Plankton Res. 26: 875-883. http://dx.doi.org/10.1093/plankt/fbh079

ICES 2011. Report of the ICES - IOC Working Group on Harmful Algal Bloom Dynamics (WGHABD), 5-8 April 2011, Gothenburg, Sweden. ICES CM 2011/SSGHIE, 42 pp.

Ichimi K., Suzuki T., Ito A. 2002. Variety of PSP toxin profiles in various culture strains of Alexandrium tamarense and change of toxin profile in natural A. tamarense population. J. Exp. Mar. Biol. Ecol. 273: 51-60. http://dx.doi.org/10.1016/S0022-0981(02)00137-5

Igarashi T., Satake M., Yasumoto T. 1996. Prymnesin-2: a potent ichthyotoxic and haemolytic glycoside isolated from the red tide algae Prymnesium parvum. J. Am. Chem. Soc. 118: 479-480. http://dx.doi.org/10.1021/ja9534112

Johnsen M., Eikrem W., Olseng D.C. et al. 2010. Prymnesium parvum: The Norwegian Experience. J. Am. Water Resour. As. 46: 6-13. http://dx.doi.org/10.1111/j.1752-1688.2009.00386.x

Lemée R., Pesando D., Durand-Clément M. et al. 1993. Preliminary survey of toxicity of the green alga Caulerpa taxifolia introduced intro the Mediterranean. J. Appl. Phycol. 5: 485-493. http://dx.doi.org/10.1007/BF02182507

Manning S.R., La Claire J.W. 2010. Prymnesins: toxic metabolites of the golden alga, Prymnesium parvum Carter (Haptophyta). Mar. drugs. 8: 678-704. http://dx.doi.org/10.3390/md8030678

Martins C.A., Kulis D., Franca S. et al.. 2004. The loss of PSP toxin production in a formerly toxic Alexandrium lusitanicum clone. Toxicon. 43: 195-205. http://dx.doi.org/10.1016/j.toxicon.2003.11.023

Menchaca I. 2010. Desarrollo y aplicación de herramientas para la evaluación de la calidad del medio marino del País Vasco: Bioensayos con Paracentrotus lividus y Corphium sp. PhD thesis, University of the Basque Country, $220 \mathrm{pp}$

Moestrup Ø. 1994. Economic aspects: 'blooms', nuisance species, and toxins. In: Green, J.C. and Leadbeater, B.S.C., (eds), The Haptophyte Algae. Clarendon Press, Oxford. 265-285.

Montoya N.G., Fulco V.K., Carignan M.O. et al. 2010. Toxin variability in cultured and natural populations of Alexandrium tamarense from southern South America - Evidences of diversity and environmental regulation. Toxicon. 56: 1408-1418. http://dx.doi.org/10.1016/j.toxicon.2010.08.006

OSPAR 2005. Protocols on methods for the testing of chemicals used in the offshore oil industry. OSPAR Commission. $35 \mathrm{pp}$.

Paul V.J., Fenical W. 1984. Bioactive terpenoids from Caribbean marine algae of the genera Penicillus and Udotea (Chlorophyta). Tetrahedron. 40: 2913-2918. http://dx doi.org/10.1016/S0040-4020(01)91301-8

Pedrotti M.L., Marchi B., Lemée R. 1996. Effect of Caulerpa taxifolia secondary metabolites on the embryogenesis, larval development and metamorphosis of the sea urchin Paracentrotus lividus. Oceanol. Acta. 19: 255-262.

Penna A., Fraga S., Masó M. et al. 2008. Phylogenetic relationships among the Mediterranean Alexandrium (Dinophyceae) species based on sequences of 5.8S gene and Internal Transcript Spacers of the rRNA operon. Eur. J. Phycol. 43: 163-178. http://dx.doi.org/10.1080/09670260701783730

Pérez V. 2006. La utilización de anfípodos para la evaluación integrada de la calidad de sedimentos marinos y estuáricos: su aplicación en la costa vasca. $\mathrm{PhD}$ thesis, University of the Basque Country, 197 pp.

Pérez S., Beiras R. 2010. The mysid Siriella armata as a model organism in marine ecotoxicology: comparative acute toxicity sensitivity with Daphnia magna. Ecotoxicology. 19: 196-206. http://dx.doi.org/10.1007/s10646-009-0405-3

Pohnert G. 2000. Wound- activated chemical defense in unicellular planktonic algae. Angew. Chem. Int. Edit. 39: 4352-4354.

Privitera D., Giussani V., Isola G. et al. 2012. Toxic effects of $O s$ - 
treopsis ovata on larvae and juveniles of Paracentrotus lividus. Harmful Algae. 18: 16-23.

http://dx.doi.org/10.1016/j.hal.2012.03.009

Remmel E.J., Kohmescher N., Larson J.H. et al. 2011. Experimental study of harmful algae-zooplankton interactions and the ultimate grazing defense. Limnol. Oceanogr. 56: 461-470. http://dx.doi.org/10.4319/lo.2011.56.2.0461

Remmel E.J., Hambright K.D. 2012. Toxin-assisted micropredation: experimental evidence shows that contact micropredation rather than exotoxicity is the role of Prymnesium toxins. Ecol. Lett. 15: 126-132. http://dx.doi.org/10.1111/j.1461-0248.2011.01718.x

Ribo J.M., Kaiser K.L.E. 1987. Photobacterium phosphoreum toxicity bioassay. I. Test procedures and applications. Toxic. Assess. 2: 305-323

Romano G., Russo G.L., Buttino I. et al. 2003. A marine diatomderived aldehyde induces apoptosis in copepod and sea urchin embryos. J. Exp. Biol. 206: 3487-3494. http://dx.doi.org/10.1242/jeb.00580

Sarabia R. 2002. Toxicidad y acumulación de cadmio en poblaciones de diferentes especies de Artemia. PhD thesis, University of Valencia, $138 \mathrm{pp}$.

Seoane S., Eikrem W., Arluzea J. et al. 2009. Haptophytes of the Nervión River estuary, northern Spain. Bot. Mar. 52: 47-59. http://dx.doi.org/10.1515/BOT.2009.027

Sorgeloos P., Remiche-Van Der Wielen C., Persoone G. 1978. The use of Artemia nauplii for toxicity tests-A critical analysis. Ecotoxicol. Environ. Saf. 2: 249-255.

USEPA 2001. Method for assessing the chronic toxicity of marine and estuarine sediment-associated contaminants with the amphipod Leptocheirus plumulosus. EPA 600/R-01/020. 102 pp.

USEPA 2002. Short-term Methods for Estimating the Chronic Toxicity of Effluents and Receiving Waters to Marine and Estuarine Organisms. Third Edition, environmental Monitoring Systems. Laboratory, U.S. Environmental Protection Agency, Cincinnati, EPA 821/R-02/014. 464 pp.

Varela D., Paredes J., Alves-de-Souza C. et al. 2012. Intraregional variation among Alexandrium catenella (Dinophyceae) strains from southern Chile: Morphological, toxicological and genetic diversity. Harmful Algae. 15: 8-18. http://dx.doi.org/10.1016/j.hal.2011.10.029

Yasumoto T., Oshima Y., Yamaguchi M. 1978. Occurrence of a new type of shellfish poisoning in the Tohoku district. B. Jpn. Soc. Sci. Fish. 44: 1249-1255. http://dx.doi.org/10.2331/suisan.44.1249

Zhenxing W., Yinglin Z., Mingyuan Z. et al. 2006. Effects of toxic Alexandrium species on the survival and feeding rates of brine shrimp, Artemia salina. Acta Ecol. Sin. 26: 3942-3947. http://dx.doi.org/10.1016/S1872-2032(07)60004-3

Zon L.I., Peterson R.T. 2005. In vivo drug discovery in the zebrafish. Nat. Rev. Drug. Discov. 4: 35-44.

http://dx.doi.org/10.1038/nrd1606 